\title{
Current policy priorities and regulatory approaches for irrigation and associated challenges of 'farmer- led' irrigation development in Tanzania
}

\begin{abstract}
In this article we contribute to the discussion on Irrigating Africa-Reframing Agricultural Investment by focusing on current policy priorities and regulatory approaches for irrigation and associated challenges of 'farmer-led' irrigation development in Tanzania. Just like other developing countries, Tanzania has ambitious plans and has committed to expand irrigated agriculture through the National Irrigation Commission (NIRC) which has legal mandate to coordinate, promote and regulate the irrigation sector. Irrigation is important in Tanzania to deal with the erratic rainfall, especially in the context of climate change. In view of these, the Government has been taking various measures including establishment of the National Irrigation Commission (NIRC), the formulation of national policies (NIP), National Irrigation Act (NIA), National Irrigation Regulations (NIR) and their Strategies that are strongly recognizing the importance of irrigation towards the increase in food security and the economy at both household and national level. This article was based on official government documents related to irrigation development; consultation with the National Irrigation Commission (NIRC) and related Zonal Irrigation Offices (ZIOs) distributed throughout the country as well as various irrigation schemes (IS) and their respective irrigators organizations (IOs). Results shows that although there are huge opportunities for Irrigation Development in Tanzania, farmers led irrigation is faced by a number of constraints including slow or delayed implementation of irrigation Act 2013 and its regulations 2015; inadequate access to affordable long-term funding/ financing for irrigation investments; low capacity and participation of private sector in irrigation development and weak Irrigators Organizations (IOs). In conclusion, for any meaningful small scale farmer or farmer-led irrigation in Tanzania, there is a need for the Government to adequately and fully support the NIRC to effectively play its role of coordination, promotion and regulation through the implementation of the National Irrigation Act, National Irrigation Regulations and the Revised National Irrigation Master Plan (RNIMP) which addresses the aforementioned constraints facing farmerled irrigation in Tanzania.
\end{abstract}

Keywords: water use efficiency, climate change, irrigation policy, national irrigation act, irrigation regulations
Volume 2 Issue 3 - 2018

\author{
Joachim HJR Makoi,' Eliakim C Matekere ${ }^{2}$ \\ 'Ministry of Water and Irrigation, National Irrigation \\ Commission (NIRC), Tanzania \\ ${ }^{2}$ Department of Research and Technology Promotion, National \\ Irrigation Commission, Tanzania
}

\begin{abstract}
Correspondence: Joachim Makoi, Ministry of Water and Irrigation, National Irrigation Commission, P.O.Box 6668, Dar es Salaam, Tanzania, Tel +2557 62293254 ,
\end{abstract}

Email joachimmakoi@yahoo.com

Received: April 28, 2018 | Published: June 13, 2018
Abbreviations: NIRC, national irrigation commission; NIP, national policies; NIA, national irrigation act; ZIOs, zonal irrigation offices; IS, irrigation schemes; IOs, irrigators organizations; RNIMP, revised national irrigation master plan; URT, united republic of Tanzania; NFRs, national food requirements; GDP, gross domestic product; ASDS, agriculture sector development strategy; ASDP, agriculture sector development programme; TDV, Tanzania development vision; RDS, rural development strategy; MDGs, millennium development goals; NIMP, national irrigation master plan; NSGRP, national strategy for growth and reduction of poverty; IWRM, integrated water resources management; IDF, irrigation development fund; SAGCOT, southern agricultural growth corridor of Tanzania

\section{Introduction}

The United Republic of Tanzania (URT) is situated in East Africa and has an area of $945,087 \mathrm{~km}^{2}$. It is bordered by Kenya and Uganda to the north; Rwanda, Burundi and the DRC to the west; Zambia, Malawi and Mozambique to the south; and the Indian Ocean to the east. The national census carried out in 2012 showed that the population in Tanzania was $45 \mathrm{~m} .{ }^{1}$ However, in 2018 the UN estimated Tanzania's population to be about $59 \mathrm{~m}$.

The economy of Tanzania is to a large extent dependent on agriculture, which accounts for about $24.5 \%$ of GDP, ${ }^{2} 85 \%$ of exports $^{3}$ and during years with sufficient rainfall, it contributes $100 \%$ and in $2016 / 17$ cropping season, $123 \%$ of the national food requirements (NFRs). Currently, agriculture employs nearly $70 \%$ of population and contributed about $29.1 \%$ of the GDP in 2016. Even though agriculture has significant role in the national economy, its production and productivity is low because to a large extent it depends on rainfall which is seasonally erratic, unreliable and non-uniformly distributed. Due to non-optimal availability of water for crop production, frequent food shortages have continued to be experienced in the country. Tanzania will therefore need to boost crop production 4 folds (i.e. from 1.8 to $7.2 \mathrm{tha}^{-1}$ ) by improvement and or construction of 
irrigation infrastructure to take advantage of exploiting huge potential area amounting to $29.4 \mathrm{~m} \mathrm{Ha}$.

Irrigation development and practices is viewed as a strategy to mitigate the impacts of climate variability as well as one of the effective means in increasing and stabilising crop productivity; minimizing food shortages and maximizing export of cash crop and its products. Whereas Large-scale irrigation schemes have the potential to buffer farmers from dependence on food aid in times of crop failure and drought; ${ }^{4}$ small-scale irrigation is seen as key to improving agricultural productivity and resilience of rural livelihoods. ${ }^{5-7}$ In this context, the National Irrigation Policy (NIP) has come at the right time amidst shocks due to global increase in food insecurity and prices. This article was based on official government documents related to irrigation development; consultation with the National Irrigation Commission (NIRC) and related Zonal Irrigation Offices (ZIOs) distributed throughout the country as well as various irrigation schemes (IS) and their respective irrigators organizations (IOs).

\section{Total irrigation development potential in Tanzania}

Tanzania has $94.5 \mathrm{~m} \mathrm{Ha}$ of land of which about $47 \%$ are classified as arable and $23.0 \%$ of the arable land are cultivated. Based on water and land resources; socio-economic aspects like improvement of roads infrastructure and increase in the demand of irrigation by stakeholders, total irrigation development potential in Tanzania is $29.4 \mathrm{~m} \mathrm{Ha}{ }^{8,9}$ Out of the total potential, $8 \%$ are of high potential; $16 \%$ are of medium potential; and $76 \%$ are of low potential. As of March 2017 only $1.6 \%$ was provided with improved irrigation infrastructure which contributed $24 \%$ of the total NFR (Table 1). Currently, NIMP ${ }^{8}$ is under review and depending on the change in social and economic aspects, irrigation potential areas are subject to change. It is expected that by 2030 the area provided with irrigation infrastructure for small, medium and large scale irrigation schemes will be $1 \mathrm{~m}$ Ha. During the same period of time irrigation infrastructure in 176 irrigation schemes will be completed, 205 irrigation schemes and 30 climate resilient structures will be rehabilitated; and 40 new climate resilient structures will be constructed for irrigation and other uses. These important expectations are subject to adequate and prompt availability of financial resources from the government, private sector and/or development partners (Figure 1).

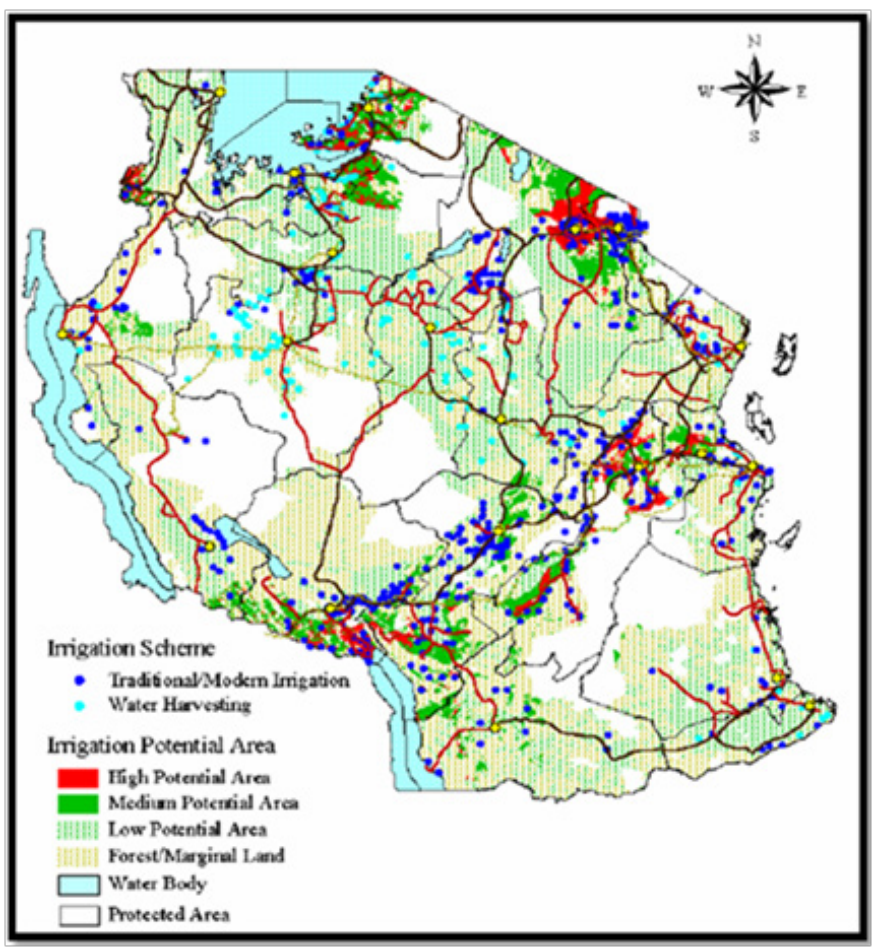

Figure I Irrigation scheme in tanzania.

\section{Historical events and previous status of irrigation development in Tanzania}

Irrigation developments in Tanzania have witnessed several events since 1930s and have been shifted from Ministry to Ministry or from Department to Department in a very short range of time (Table 1). Similarly, Irrigation development has had different status since 1960s where only 2,600 Ha was achieved in 1970 out of 20,000 Ha that were targeted between 1960 and 1980 (Table 2) due to unrealistic planning and weak coordination. Although Irrigation intervention within the regional authorities was undertaken between 1975 and 1979, it was unsuccessful because the regional programs were similarly inadequately planned, staffed, equipped and financed.

Table I Historical events of irrigation development in Tanzania

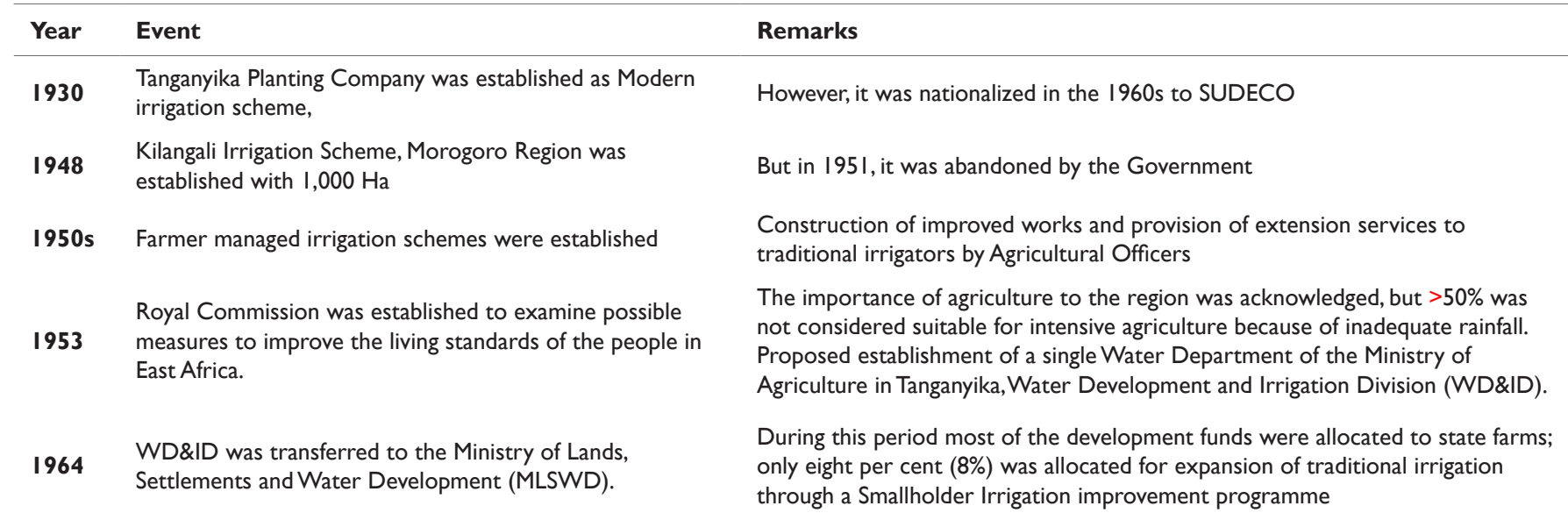

Citation: Makoi JHJR, Matekere EC. Current policy priorities and regulatory approaches for irrigation and associated challenges of 'farmer-led' irrigation development in Tanzania. Forest Res Eng Int J. 2018;2(3):I52-I6I. DOI: 10.15406/freij.2018.02.0004I 
Table Continued....

\begin{tabular}{|c|c|c|}
\hline Year & Event & Remarks \\
\hline 1968 & Irrigation section in Ministry of Agriculture was established & $\begin{array}{l}\text { Staff posted mostly to the Regional Agricultural Development Officers (RADOs) } \\
\text { to support smallholder traditional irrigators. }\end{array}$ \\
\hline 1973 & $\begin{array}{l}\text { WD\&ID was shifted from the MLSWD to the Ministry of } \\
\text { Water Development and Power. }\end{array}$ & \\
\hline 1975 & $\begin{array}{l}\text { The responsibility for irrigation was reverted to the } \\
\text { Ministry of Agriculture, which had no capacity for the task. }\end{array}$ & $\begin{array}{l}\text { WD\&ID was therefore disbanded with most of its staff remaining with the } \\
\text { Ministry of Water and Power. }\end{array}$ \\
\hline 1975 & Irrigation Division was initiated. & Since this year, Irrigation HQs has been changed 6 times \\
\hline 1987 & Restructuring of the Ministry of Agriculture. & $\begin{array}{l}\text { Reduced the Division of Irrigation to a section, led by an Assistant } \\
\text { Commissioner in a newly formed Division of Agriculture and Livestock } \\
\text { Development. }\end{array}$ \\
\hline 2002 & $\begin{array}{l}\text { Irrigation Section was elevated to a Division of Irrigation } \\
\text { and Technical Services with three sections. }\end{array}$ & \\
\hline 2004 & $\begin{array}{l}\text { Modern irrigation, Tanganyika Planting Company was } \\
\text { privatized }\end{array}$ & \\
\hline 2008 & $\begin{array}{l}\text { Division of Irrigation and Technical Services was transferred } \\
\text { to the newly formed Ministry of Water and Irrigation. }\end{array}$ & $\begin{array}{l}\text { Since } 1975 \text {, Irrigation HQs has been changed } 6 \text { times mostly due to inadequate } \\
\text { office space; the Division had to occupy more than one building with distant } \\
\text { locations creating unnecessary disturbances and low working performance }\end{array}$ \\
\hline 2012 & Establishment of National Irrigation Commission & Under the Ministry of Agriculture food and Security \\
\hline 2015 & The NIRC was shifted from MAFS & Ministry of Water and Irrigation \\
\hline 2018 & NIRC may be shifted again & To Dodoma the National Capital City \\
\hline
\end{tabular}

Table 2 Previous status of irrigation development in Tanzania

\begin{tabular}{clll}
\hline Year Description & Units & Target period & Reasons for not achieving the target \\
\hline Target Area $\quad$ Achieved Area &
\end{tabular}

$1970 \quad 20,000$

2,600

Unrealistic and weakly coordinated planning resulting in slow development of new irrigation schemes; low impetus by the Government (until 1974/75 when the country was faced with a serious drought that resulted in a major food crisis); decentralization reforms which created a vacuum in institutional capability for irrigation development

Irrigation intervention within the Regional Authorities. However,

1975-1979 the regional programs were not successful because they were poorly planned, under-staffed, under-equipped and underfinanced.

Development goals were revised with emphasis on the rehabilitation and upgrading of village irrigation schemes (National

$\begin{array}{llll}1980 \quad 150,000 \quad H a & \text { Ha }\end{array}$

Village Irrigation Development Project-NVIDP) around the country varying in size from 200 to 2,000 ha and a target of 150,000 ha was set.

Technical support units at six Zonal irrigation units were established each comprising of three to four regions for the purpose of complementing the capabilities at the Regional Authorities in the implementation of irrigation development.

Irrigation sector received major institutional capacity building 1986-1995 support from external development partners particularly at the headquarters division level and at the established Zonal Irrigation Units.

Set targets for infrastructural improvement.

Schemes

Division had recruited 92 professional staff and 197 technical staff of various disciplines, but because of limited practical experience, most of them had not achieved adequate capacity and confidence to operate effectively. 
Table Continued....

\begin{tabular}{cllll}
\hline Year & Description & Units & Target period & Reasons for not achieving the target \\
\hline Target Area & Achieved Area & & \\
\hline & 60 & $\begin{array}{l}\text { Irr. } \\
\text { Schemes }\end{array}$ & 2002 & $\begin{array}{l}\text { Only } 30 \% \text { of the activities for removal of constraints had been } \\
\text { achieved and only } 60 \text { irrigation schemes out of the set target } \\
\text { were implemented. }\end{array}$ \\
\hline
\end{tabular}

\section{Opportunities for irrigation development in Tanzania}

Several opportunities for developing irrigation systems in Tanzania have been earmarked. ${ }^{10}$ Firstly, there is huge potential area for irrigation development ${ }^{8}$ as well as surface and ground water resources organized into nine (9) basins for effective management, planning and development (Figure 1). These basins hold all the surface and ground water in the country for all uses, including irrigation. Secondly, there is a prodigious prospect for market of rice and other crops from irrigated agriculture due to population increase within and beyond the borders. ${ }^{1}$ Based on United Nations, the population of Tanzania is currently estimated as 59m as of April 2018 compared with $45 \mathrm{~m}$ in 2012. ${ }^{1}$ More water is therefore needed to grow more rice to tally with the burgeoning population. In Tanzania, rice is the most irrigated crop, second most important food crop after maize, ${ }^{11}$ second largest produced crop in eastern Africa $^{12}$ with per capital consumption of about $25 \mathrm{~kg}$ and the leading commercial food crop, as $42 \%$ of it is marketed. ${ }^{13,14}$ Thirdly, there is potential demand for rice from the neighbouring countries, which are not similarly endowed with high irrigation potential. Based on the latest United Nations estimates the population of Eastern Africa alone is $432 \mathrm{~m}$, as of April 2018, suggesting that regional markets are gradually growing, and provides an important stepping stone for the expansion of agricultural exports. By developing new markets, it is likely for Tanzania to attain economies of scale, drive down production costs, and achieve lower freight costs to markets beyond the border. Fourthly, Tanzania's location is such that it can be easily reachable and suitable for export outlets to external markets. Fifthly, presence of experienced irrigation experts with wider knowledge coverage is of unlimited chance; however, the number is inadequate. As such, high priority to irrigation development has greatly been accentuated within the National Irrigation Policy Frameworks. The Government is also giving high priority to the management of the nation's water resources which offers strong synergies with irrigation development.

\section{The need for irrigation policy in Tanzania}

The need to have the NIP ${ }^{10}$ with a view to transform irrigated agriculture has been the focus of different policies, acts and strategies of the governments of all previous phases. ${ }^{15}$ For example, some initiatives made during the phase I government include the villagization and the Iringa declaration policies which underlined the use of irrigation besides other aspects of agricultural modernization. During the Phase IV Government in 2006, Agriculture Sector Development Strategy (ASDS) and the Agriculture Sector Development Programme (ASDP) were completed. Similarly, in 2009, a new strategy named 'Kilimo Kwanza' was designed which accurately fastened the engrossment of the private sector in the development of irrigated agriculture, thus, accentuating the critical importance of the private sector along the value chain.
Other related policies and strategies include National Irrigation Development Plan (NIDP), 1994; Agricultural and Livestock Policy of 1997; Tanzania Development Vision (TDV-2025) of 2000; Rural Development Strategy (RDS) December, 2001; Millennium Development Goals (MDGs) 2002; National Irrigation Master Plan (NIMP) 2002; National Strategy for Growth and Reduction of Poverty (NSGRP-MKUKUTA) June 2005; and the Agricultural Sector Development Programme (ASDP), 2006. All these sector policies address irrigation interventions, even though thinly, as having a vital input in crop production and productivity for increased food security and income to farmers at small, medium and large scale levels. Inadequate involvement of private sector and ineffectiveness of the existing irrigation schemes has ominously contributed to the overall low crop production in Tanzania. Moreover, there has been unclear ownership of irrigation infrastructure prevailing in some irrigation schemes at different levels, which has led to irrigation inefficiencies and poorly maintained irrigation infrastructure suggesting a need for an irrigation policy to direct development in the irrigation sector. In view of these gaps, the government formulated the National Irrigation Policy $^{10}$ which led to establishment National Irrigation Act 2013 (NIA), National Irrigation Commission (NIRC) and Regulations 2015 (NIR) to spearhead the implementation of irrigation interventions for agricultural production and productivity.

\section{National irrigation policy and its priorities in Tanzania}

The NIP Vision is a sustainable and dynamic irrigation sector that is a driving force in transforming agriculture into a stable, highly productive, modernised, commercial, competitive and diversified sector which generates higher incomes; increases food security and stimulates economic growth. ${ }^{10}$ Its mission is to facilitate a participatory demand driven irrigation development through Integrated Water Resources Management (IWRM) to enhance WUE for greater and justifiable agricultural productivity for food security, poverty reduction, and national economic income. The main objective is to ensure sustainable availability of irrigation water and its efficient use for higher crop productivity and profitability. To achieve the main objective, several specific objectives were set as priorities: To accelerate investment in the irrigation sector by both public and private sector; ensure that Irrigation development funds are legally established; promote WUE in irrigation systems; abide by the IWRM approach in irrigation development; ensure that irrigation development is technically feasible; ensure reliable irrigation water for optimum intensification and diversification of irrigated crops; ensure demand driven irrigation development models responsive to market opportunities; strengthen institutional capacity at all levels of irrigation development with regards to planning, implementation and management; empower beneficiaries for participatory irrigation 
planning, implementation and O\&M; strengthen research, technical support services, development and dissemination of new practices, innovations and technologies on irrigation and drainage; and mainstream cross cutting issues in irrigation development.

\section{National irrigation act $20 / 3$ for irrigation development in Tanzania}

The NIA No. 5 of 2013 in Tanzania offers for the formation of the NIRC (which plays the role of coordination, promotional and regulatory functions in the development of the irrigation sector); development, O\&M of irrigation and drainage systems; effective implementation the National Irrigation Policy, ${ }^{10}$ the National Irrigation Development Strategy (NIDS) and other related matters. The NIA No. 5 of 2013 contains ten (10) sections as shown in Table 3. These sections include: Preliminary Provisions, Administration, Declaration of Irrigation Area and Land Classification, Construction of Irrigation Works, Categorization and Approval of Irrigation Schemes and Irrigators, Management of Irrigation Schemes, Environmental and Health Protection, Financial Provisions, Offences and Penalties, General Provisions

Table 3 The national irrigation act outlines

\begin{tabular}{|c|c|c|c|}
\hline Part & Section title & S/No & Description \\
\hline \multirow[t]{2}{*}{ I } & Preliminary Provisions & $\mathrm{I}$ & Short title and commencement. \\
\hline & & 2 & Interpretation \\
\hline \multirow[t]{14}{*}{ II } & Administration & 3 & Establishment of National Irrigation Commission. \\
\hline & & 4 & Investment in the Irrigation development. \\
\hline & & 5 & Functions and powers of the Commission. \\
\hline & & 6 & Committees of the Commission. \\
\hline & & 7 & Seal of the Commission. \\
\hline & & 8 & Appointment of the Director General. \\
\hline & & 9 & Appointment of other Directors. \\
\hline & & 10 & Staff of the Commission. \\
\hline & & II & Regional Irrigation Offices. \\
\hline & & 12 & Regional Secretariat. \\
\hline & & 13 & District Irrigation Department. \\
\hline & & 14 & Appointment of Irrigation Inspectors. \\
\hline & & 15 & Powers of Irrigation Inspector. \\
\hline & & 16 & Restriction of unqualified Irrigation Inspector. \\
\hline \multirow[t]{3}{*}{ III } & $\begin{array}{l}\text { Declaration of Irrigation Area and Land } \\
\text { Classification }\end{array}$ & 17 & Declaration of irrigation area. \\
\hline & & 18 & Land acquisition for irrigation development. \\
\hline & & 19 & Classification of Irrigation land. \\
\hline \multirow[t]{7}{*}{ IV } & Construction of Irrigation Works & 20 & Undertaking of irrigation works. \\
\hline & & 21 & Application for construction of irrigation works. \\
\hline & & 22 & Construction and commissioning of irrigation works by Commission. \\
\hline & & 23 & Consequences of construction of irrigation works. \\
\hline & & 24 & Compensation for damage suffered due to construction of irrigation works. \\
\hline & & 25 & Entrustment of irrigation works. \\
\hline & & 26 & Construction of minor irrigation works. \\
\hline \multirow[t]{2}{*}{$\mathrm{V}$} & $\begin{array}{l}\text { Categorization and Approval of Irrigation } \\
\text { Schemes and Irrigators }\end{array}$ & 27 & Categorization of irrigation schemes. \\
\hline & & 28 & Categorization and approval of irrigators. \\
\hline \multirow[t]{2}{*}{ VI } & Management of Irrigation Schemes & 29 & Management of irrigation schemes. \\
\hline & & 30 & Establishment of irrigators' organizations. \\
\hline
\end{tabular}


Table Continued...

\begin{tabular}{|c|c|c|c|}
\hline Part & Section title & S/No & Description \\
\hline & & 31 & Objects of the Irrigators' Organizations. \\
\hline & & 32 & Functions of the Irrigators' Organizations. \\
\hline & & 33 & Sources of funds for the Irrigators' Organizations. \\
\hline & & 34 & Procedure for taking up works. \\
\hline & & 35 & Allocation of irrigation plots. \\
\hline & & 36 & Disputes settlement on irrigation schemes. \\
\hline & & 37 & Withdraw and surrender of irrigation plots. \\
\hline & & 38 & $\begin{array}{l}\text { Power to prescribe good agricultural practices and irrigation methods in the } \\
\text { irrigation area. }\end{array}$ \\
\hline & & 39 & Power to take over irrigation works. \\
\hline & & 40 & Irrigation service fees. \\
\hline & & $4 I$ & Operation and maintenance of irrigation schemes. \\
\hline & & 42 & Clearance of banks. \\
\hline & & 43 & Commission to order provision of proper banks. \\
\hline & & 44 & $\begin{array}{l}\text { Procedure on failure to contribute for the cost or labour for work to be } \\
\text { done by joint labour. }\end{array}$ \\
\hline & & 45 & Distribution of water from Irrigation works. \\
\hline & & 46 & Prohibited acts. \\
\hline & & 47 & $\begin{array}{l}\text { Obligation of land owners in respect of works affecting safety of the } \\
\text { irrigation works. }\end{array}$ \\
\hline & & 48 & Control of navigation and unplanned canal crossings. \\
\hline & & 49 & Inter-basin water transfer for irrigation. \\
\hline & & 50 & Monitoring and evaluation or performance of irrigation schemes. \\
\hline \multirow[t]{2}{*}{ VII } & Environmental and Health Protection & 51 & Compliance with environmental requirement. \\
\hline & & 52 & Commission to coordinate and promote irrigation research \\
\hline \multirow[t]{10}{*}{ VIII } & Financial Provisions & 53 & Establishment of the Irrigation Development Fund \\
\hline & & 54 & Use of the Fund \\
\hline & & 55 & Advances to the Fund. \\
\hline & & 56 & Management of the Fund. \\
\hline & & 57 & Accounts and Audit of the Irrigation Development Fund. \\
\hline & & 58 & Funds of the Commission. \\
\hline & & 59 & Annual budget of the Commission. \\
\hline & & 60 & Accounting and audit. \\
\hline & & 61 & Powers to borrow and invest. \\
\hline & & 62 & Financial year. \\
\hline \multirow[t]{3}{*}{ IX } & Offences and Penalties & 63 & Offences and penalties. \\
\hline & & 64 & Offence by body corporate or firm. \\
\hline & & 65 & Civil liability not affected. \\
\hline \multirow[t]{6}{*}{$X$} & General Provisions & 66 & Duty of secrecy. \\
\hline & & 67 & Service of notices. \\
\hline & & 68 & Keeping records. \\
\hline & & 69 & Stakeholders' meeting. \\
\hline & & 70 & Commission to call for information. \\
\hline & & 71 & Powers of the Minister to require information. \\
\hline
\end{tabular}


Table Continued...

\begin{tabular}{lll}
\hline Part Section title & S/No & Description \\
\hline 72 & 73 & Commission to establish and maintain collaboration. \\
74 & Recovery of cost of repairing damage where an offender is unascertainable. \\
75 & Mode of recovery of money. \\
76 & Powers to make Regulations. \\
77 & Transitional provisions.
\end{tabular}

\section{Irrigation regulation approaches in Tanzania}

The Irrigation Regulations in Tanzania were established in 2015 with a view to implement the National Irrigation Act, 2013 (Act No. 5 of 2013). These Regulations are grouped into five parts as summarized in Table 4. They include: Preliminary; Formation, Registration, Procedures and Conduct of Irrigators' Organizations; Formulation of Irrigation Projects and Construction of Irrigation Works; Maintenance of Irrigation Works; and Miscellaneous. These regulations aims to better shape the irrigation development in Tanzania to meet the mission and vision of the National Irrigation Policy

Table 4 Summary of status of registered irrigators organizations, associations and cooperatives in all the irrigation zones in tanzania

\begin{tabular}{lllll}
\hline S/No & Zone name & \multicolumn{4}{l}{ Registered as IC, IA or IO-NIRC } \\
\hline & & IC & IA & IO-NIRC \\
\hline I & Dodoma & 20 & 28 & I \\
2 & Kilimanjaro & 30 & 40 & 3 \\
3 & Mbeya & 17 & 118 & - \\
4 & Morogoro & 8 & 46 & - \\
5 & Mtwara & 5 & 82 & - \\
6 & Mwanza & - & 37 & - \\
7 & Tabora & 9 & 14 & 2 \\
& Total & $\mathbf{8 9}$ & $\mathbf{3 6 5}$ & $\mathbf{5 5 *}$
\end{tabular}

Note: ICs = Irrigators Cooperatives as Registered by Cooperative Act; IAs = Irrigators Associations as Registered by Ministry of Home Affairs; IO-NIRC = Irrigators Organization as Registered by the National Irrigation Commission.

\section{Investment trend in irrigation development}

Funding for irrigation development is mostly through the Government budget which includes Government own funds and support from the development partners. Contributions from the beneficiaries are relatively minimal and usually in kind. Although the budget for irrigation development has been increasing gradually over the years, the amount allocated and disbursed has been far below the requirements. Table 5 presents the Financial Flow from 2012/13 to date. The data shows that the approved annual budget and expenditure of NIRC for the last five fiscal years. It indicates that the percentage of expenditure against approved budget for development budget is $21.1 \%$ on the average, declining from $46.7 \%$ in $2012 / 13$ to $9.4 \%$ in $2016 / 17$. Similarly, the operation expenditure decreased drastically from TZS $751 \mathrm{~m}$ in 2012/13 to TZS $300 \mathrm{~m}$ in 2016/17. This suggests that most of NIRC's staff might be compelled to wait for works in their offices because of small fund disbursement for development and operation especially in 2015/16 and 2016/17 financial years.

In that regard, the National Irrigation Act No. 5 of 2013, Part VIII Section 52 establishes the Irrigation Development Fund for ensuring sustainability of the irrigation sector. The strategy for establishing and implementing effective financing mechanisms for irrigation development are to: mobilize local and foreign financial resources for irrigation development; operationalize Irrigation Development Fund (IDF) and allocate timely adequate funds for studies, designs, irrigator's mobilization, construction, supervision and commissioning.

Table 5 Investment through Government budget

\begin{tabular}{lllllll}
\hline Budget & Source & $\mathbf{2 0 1 2 / 1 3}$ & $\mathbf{2 0 1 3 / 1 4}$ & $\mathbf{2 0 1 4 / 1 5}$ & $\mathbf{2 0 1 5 / 1 6}$ & $\mathbf{2 0 1 6 / 1 7}$ \\
\hline DB-A & Local & $11,000,000,000$ & $10,000,000,000$ & $15,000,000,000$ & $6,000,000,000$ & $6,000,000,000$ \\
& Foreign & $5,414,154,200$ & $16,391,716,100$ & $18,933,020,000$ & $47,394,574,000$ & $29,369,529,428$ \\
& Total Approved & $16,414,154,200$ & $26,391,716,100$ & $33,933,020,000$ & $53,394,574,000$ & $35,369,529,428$ \\
& Local & $2,257,694,000$ & $3,400,000,000$ & 0 & 0 & $2,239,980,000$ \\
\multirow{2}{*}{ DB-D } & Foreign & $5,414,154,100$ & $5,089,683,500$ & $10,659,134,613$ & $5,131,032,895$ & $1,101,177,000$ \\
& Total Disbursed & $7,671,848,100$ & $8,489,683,500$ & $10,659,134,613$ & $5,131,032,895$ & $3,341,157,000$
\end{tabular}

DB-A, Development Budget Approved; DB-D , Development Budget Disbursed. 


\section{Commercializing smallholder production}

The SouthernAgricultural Growth Corridor of Tanzania(SAGCOT) initiative was established in 2010 in Dar es Salaam, Tanzania with a view to support efforts being undertaken by the Government of Tanzania, at bringing about the green revolution. One of the main objectives was to give chances for smallholder producers to engage in gainful agriculture through 'investor and outgrower' relationship that allow smallholders surrounding the large-scale farms to access inputs and services along the value chain. Similarly, SAGCOT supported smallholder producer associations and or organizations to enter into rightful commercial relationships with agro-processing and marketing and provided irrigation through professionally-managed farm blocks. It is projected that by $2030,350,000 \mathrm{Ha}$ will be in profitable production, serving regional and international markets; tens of thousands of smallholders transformed into commercial farmers, covered with irrigation and weather insurance. At least 420,000 new employment opportunities will be available; greater than two (2) million people permanently lifted out of poverty; $\$ 1.2$ billion annual farming revenues achieved and regional food security would be assured. In 2017, WB approved US\$70 out of 75 million for SAGCOT Investment Project (SIP) to support Tanzania's agriculture sector and strengthen it by linking smallholder farmers to agribusinesses for boosting incomes and job-led growth. As a result, SIP will boost income opportunities for 100,000 smallholder farming households by expanding partnerships with agribusinesses in the Southern Corridor of Tanzania; directly benefit over half a million people and engage up to 40 agribusiness operators, with emphasis on including women in successful commercial value chains.

\section{Challenges facing small scale farmer-led irrigation development}

Rice is the third most important food crop in Tanzania after maize and cassava. Wilson \& Lewis ${ }^{16}$ reported that annual rice production doubled between 2001 and 2012 with an average of about $1.35 \mathrm{~m}$ tons due to increased area under cultivation. Smallholder farmers grow rice on $74 \%$ of the planted area under rainfed conditions; $20 \%$ under irrigation and $6 \%$ under large-scale irrigation. In order to improve food security and exports, the government through the National Irrigation Commission (NIRC) wishes to double rice production by 2018. Currently, rice is used both for commercial and human consumption and is comparatively a preferred grain. As a result, consumption patterns have changed leading to increased domestic rice production and exports. However, several constraints have been brought to attention: They include: Slow implementation of irrigation Act 2013 along with its regulations 2015; inadequate and affordable long-term funding; low capacity and participation of private sector; weak Irrigators Organizations (IOs); low farmers' skills on irrigation; low production and inefficient marketing systems; inadequate institutional capacity at national level with respect to irrigation development; inadequate capacity of institutions at LGA to handle irrigation investments, implementation and sustainable management; low irrigation WUE and ineffective and inefficient control of irrigation water; insecure land tenure; lack of proper agricultural land use plans; inadequate irrigation production support services backed by research and technical innovation; scant farm power for various farm operations; insufficient data base for irrigation and drainage development; inadequate climate resilient facilities for irrigation water storage; competing for water demand amongst different stakeholders; changes in river flow patterns as a result of catchment degradation and climatic change; derisory market access and economies of scale; poor quality of inputs; importation of agricultural equipment; poor infrastructure; and perception of agriculture. Some of the constraints are discussed below.

\section{Insecure land tenure}

Tanzania, just like elsewhere in Africa, possession, selling or exchange of land in any form within communities or families is established by the state or by customs ${ }^{17}$ although customary rules may or may not be recognized by the state. ${ }^{18}$ Consequently, land tenure issue remains a great challenge amongst smallholder farmerled irrigation communities. Similar to other African countries, ${ }^{17,19}$ Tanzania is currently undertaking various land tenure legislation reforms to register individual and collective rights to land and natural resources as far as irrigated agriculture is concerned. According to Mdemu et al..$^{20} \&$ Moyo et al.,${ }^{21}$; only $20 \%$ of farmers in Tanzania had obtained a loan while $80 \%$ had no loan because of lack of collateral. Lack of loan poses great limitation of farmers to buy Agri-inputs at large quantities at reduced prices. Although the government is making efforts for farmers to obtain a Customary Certificate Right of Occupancy ${ }^{20}$ it is not certain that they possess sufficient land size acceptable as collateral by financial institutions.

\section{Weak irrigators organizations}

Irrigator's organization (IO) is a local farmer's organization capable of mobilizing material and labour resources for construction and maintenance, allocating rights to water use and distribution amongst farmers and water sharing conflict resolution. Irrigator's organizations (IOs) own the irrigation infrastructure under which irrigators are responsible for O\&M. ${ }^{22}$ In Tanzania, there are 460 IOs registered under 3 different laws (Table 4). Of the total, 89 are registered under Cooperative law, 316 under the Ministry of Home Affairs and 55 under the National Irrigation Act No. 5 of 2013. Generally most irrigation schemes have management problems which include poor O\&M, poor basic leadership, and inadequate farmer's skills on O\&M. ${ }^{10}$ Consequently, most IOs have been ineffective, lacking the most basic institutions and incentives for conservation and incomplete membership from famers. For example, of the 1,850 farmers in Mkilma IO in Magozi, only $28 \%$ were members. ${ }^{20}$ This suggests that the few farmers actively using their plots are disadvantaged by many who are not actively farming and not paying their share of the collectively levied water fees. Annual business plans assist IOs to incorporate essential measures such as clarity on roles and responsibilities; a crop budget; infrastructure maintenance schedule; cooperative buying of inputs and transport services; and production schedules to better meet market demands. In some of NIP ${ }^{10}$ specific objectives indicated institutional capacity strengthening, participation and empowerment of beneficiaries at all levels. Before the NIP however, the IOs had no authority to enforce payment of fees by irrigators. Interestingly, the $\mathrm{NIP}^{10}$ has established effective cost sharing and recovery mechanism so as to have the much-needed resources for substantial infrastructure maintenance in farmer-led irrigation schemes.

\section{Poor irrigation water use efficiency}

According to the NIMP, ${ }^{8}$ there are about 2,415 irrigation schemes at different status and or stage of development in Tanzania. Traditional irrigation schemes in Tanzania are characterized by poor infrastructure, poor water management and low yields. Crop yields are typically in the range of $0.8-1.0 \mathrm{tha}^{-1}$ and $1.8-2.0 \mathrm{tha}^{-1}$ for maize and paddy respectively. The existing infrastructure starting from the headworks up to the fields are all temporal, poorly constructed and pose difficulty in overall water management resulting to low water use 
efficiencies, and so, the overall poor performance of the farmer-led irrigation schemes. The $\mathrm{NIP}^{10}$ has clearly stated to promote efficient water use in irrigation systems as one of its specific objectives. In some traditional irrigation schemes salinity and water logging problems are common due to poor water management and absence of drainage infrastructure, loss of nutrients and low crop yield. Comparatively, farmers in irrigation schemes using the Full Stop wetting front detector and Chameleon soil moisture sensor have reported using $<50 \%$ of the water they used to apply saving significant labour. ${ }^{23}$ The saved water could regularly reach the tail end of canals, enabling more farming to more farmers. ${ }^{24,25}$ Policy reform is therefore needed to achieve greater water-use efficiency (WUE) in irrigation, to extend irrigated cropping and to benefit other water users.

\section{Improving market access and quality of inputs}

In Tanzania, there is not enough input and output markets. Challenges experienced are the exorbitant high prices of fertilizers, low quality inputs such as seeds, and inability to get reduced input costs based on bulk purchases. At each of the farmers in the schemes mentioned that they buy small quantities of supplies individually at higher prices from a limited number of local suppliers. ${ }^{20,21,26}$ Three key issues emerged from our assessment: access to high-quality seeds; market access; and importation of agricultural equipment.

\section{Access to high-quality seeds}

Farmer's productivity is seriously affected due to lack of high quality inputs and a well-developed and regulated seed sector. ${ }^{27,28}$ Government policies are therefore needed to ensure access to improved seeds, enforced seed quality standards, information on prices, and financial services.

\section{Market access}

Access to output markets is a major challenge to farmer-led irrigation schemes, as much produce is sold at low farm gate prices and with high post-harvest losses. Experienced high transport costs from the irrigation schemes located far from cities make farmers unaware of prices in major urban markets..$^{20,21}$ Market access is exacerbated by lack of cropping calendar, price information, and quite often, there is no collective market hence raising the costs for individual farmers and eventually a barrier to farmers' realizing better returns. In section 2.4.5 of the NIP states to increase production and productivity, ensure collaboration with other stakeholders to support the development of infrastructure including those for processing, storage, and market linkages. This is similarly emphasized in the National Irrigation Act section 29 (2) that ensure promotion of value addition and marketing infrastructure to leverage investment.

\section{Importation of agricultural equipment}

Periodic export bans prohibit access to larger and often closer regional markets. Such bans reduce incentives for farmers to invest in increasing production volumes, potentially exacerbating crop shortages in future seasons. As a result of these ad hoc bans, local financial organizations such as PASS have stopped lending to some crops producers, citing the lack of a reliable market as its primary concern. A major barrier to farmer-led irrigation development in Tanzania is the legal and bureaucratic barriers to the importation of inputs. If irrigation schemes need import of simple tools that enable farmers to enhance their agronomic practices ${ }^{23}$ unnecessary barriers should be lifted. For example, ${ }^{20}$ reported that a project incurred very high transport costs and considerable time delays in transporting necessary irrigation tools or equipment to the irrigators, exacerbated by excessive customs processes, regulations and fees. Through the NIP, the Government will ensure that conducive environment is created for the investors to invest in irrigation farming; remove all bureaucratic, financial hurdles and unnecessary barriers for irrigation development

\section{Poor infrastructure}

a) The port, local roads and the lack of use of the railroad all lead to transport obstacles that significantly increase the cost of bringing local production to market. The Tanzanian road network comprises $91,532 \mathrm{~km}$ of roads. $33,495 \mathrm{~km}$ of roads $(12,197 \mathrm{~km}$ of national roads and $21,298 \mathrm{~km}$ of regional roads) are under the authority of the Tanzania National Roads Agency, while remaining network management is handed over to local authorities. $5,537 \mathrm{~km}$ of national roads are asphalted, compared with $847 \mathrm{~km}$ in the regional network.

b) Large-scale climate resilient infrastructures, irrigation and electrification systems are generally not available and are beyond the capability of individual farmers.

c) The rural feeder road network away from the main Dar es Salaam to Mbeya road is poor. There are no temperate or cold storage facilities or reefer/container facilities readily available to agriculture along the corridor.

d) The majority of farmers lack processing services in their area. Without the stimulation of concentrated production areas, installation of efficient processing services will be hard to justify economically.

\section{Inadequate access to affordable long-term finance}

Only a few banks are lending to agriculture in any significant way. According to the Tanzania National Business Council, in 2008 the total domestic lending to agriculture was TZS 540 billion (approximately US\$360 million), of which 92 per cent went to agricultural trading. When banks do lend, it is usually on a short-term basis to fund working capital and at rates of interest that are often too high to be commercially affordable.

\section{Difficulties securing land}

i. No comprehensive land survey of the area is available. Consequently, investors have difficulty accessing information on land availability and quality. This discourages new investment in agriculture because locating suitable land is expensive and time consuming.

ii. Only limited land in Tanzania is currently secured under 'Right of Occupancy' title and available for purchase or long-term lease. Lack of security over land deters long-term investments in land clearing, soil upgrades, irrigation and fixed assets such as pack houses and storage facilities.

iii. Soils are generally deficient in nutrients, likely to be the result of years of poor husbandry without proper replenishment. However, soil structure is very good and conducive to intensive farming.

\section{Limited market access and economies of scale}

Low production volumes and poor information flows prohibit direct access to markets, resulting in reliance by the majority of smallholders on local traders (sometimes as many as seven intermediaries) and inefficient processors prior to product reaching final markets. The dispersion of smallholder farmers, their significant 
distance to markets, and the low volumes they are producing make it difficult to install infrastructure (roads and electricity) that would improve their access to markets.

\section{Conclusion}

In conclusion, there should be accelerated reformation of land tenure systems; realistic, timely and prompt availability of funds for farmer-led irrigation development; countrywide dissemination of the National Irrigation Policy (NIP), National Irrigation Act (NIA) and its Regulations (NIR); enhance irrigators organizations (IOs) by ensuring that ownership of infrastructure is clear and that they have the responsibility for collection of fees and maintenance of infrastructure; develop their business management (such as to access affordable, high-quality fertilizers and seeds) and crop marketing skills; enable more efficient water use by (a) developing local capacity and access to appropriate water serving irrigation technologies such as drip irrigation, system of rice intensification (SRI) and increase the overall water-use efficiency of production systems, and (b) developing the skills of agricultural extension officers to backstop the learning process of farmers; support irrigation business through national government policies for: (a) adoption and enforcement of the SADC Harmonized Seed Regulatory System rules to facilitate access to high-quality seed; (b) mechanisms to record and make available to farmers via radio, internet and SMS the market prices of produce in key cities; and (c) remove tariffs and bureaucratic barriers to the import of agricultural equipment and other imports.

\section{Acknowledgements}

None.

\section{Conflict of interest}

Author declares there is no conflict of interest.

\section{References}

1. PHC. Population and Housing Census. Tanzania: Department of Census and Statistics, Ministry of Finance and Planning; 2012. p. 1-102.

2. Statistical Abstract. National Bureau of Statistics. Tanzania: Tanzania Ministry of Finance; 2013.

3. CIA. Central Intelligence Agencies. Tanzania: The World Fact book; 2013.

4. Deressa TT, Hassan RM, Ringler C, et al. Determinants of farmers' choice of adaptation methods to climate change in the Nile Basin of Ethiopia. Global Environmental Change. 2009;19(2):248-255.

5. Sakaki M, Koga K. An effective approach to sustainable small-scale irrigation developments in Sub-Saharan Africa. Paddy and Water Environment. 2011;11(1-4):1-14.

6. The Montpellier Panel. Growth with Resilience: Opportunities in African Agriculture. A Montpellier Panel Report March; 2012. p. 1-34.

7. Chiroro C. Innovations to promote growth in small-scale irrigation in Africa: Malawi report. Report for the DFID Growth Research Program, led by the School of Global Studies, UK: University of Sussex; 2015.

8. NIMP. National Irrigation Master Plan. Tanzania: Ministry of Water and Irrigation; 2002.

9. URT. AGSTATS for Food Security,2007/08 Final Food Crop Production Forecast for 2008/09 Food Security-Executive Summary. Tanzania: Ministry of Agriculture Food and Cooperatives. 2009. p. 1-58.
10. NIP. National Irrigation Policy. Tanzania: Ministry of Water and Irrigation; 2010.

11. EUCORD. Rice Sector Development in East Africa. A Desk Study Prepared for Common Fund for Commodities. Belgium: European Cooperative for Rural Development; 2012. p. 1-73.

12. ACT. Value Chain Analysis of Rice and Maize in Selected Districts in Tanzania: Volume I: Introduction, Context Analysis and Recommended Way Forward. Final Report: Agricultural Council of Tanzania and Tanzania Agriculture Partnership, Study undertaken by Match Maker Associates; 2010.

13. Ian L. Tanzania's Rice Sub-Sector and Value Chain-Analysis \& Review and Proposed Vision \& Strategy for Improved Competitiveness \& Growth. Italy: FAO; 2012. p. 1-111.

14. MAFC. National Rice Development Strategy-Final Draft. Tanzania: Ministry of Agriculture, Food Security and Cooperatives, United Republic of Tanzania; 2009. p. 1-32.

15. SAGCOT. SAGCOT Investment Blueprint, Appendix IV Value Chain and Market Analysis. Tanzania: Southern Agricultural Growth Corridor of Tanzania: Dar es Salaam; 2011.

16. Wilson TA, Lewis I. The Rice Value Chain in Tanzania: A report from the Southern Highlands Food Systems Programme. Italy: FAO; 2015.

17. Garvelink WJ, Wedding K, Hanson S. Smallholder Agriculture: A Critical Factor in Poverty Reduction and Food Security in Africa. USA: CSIS; 2012.

18. ECA. Land tenure systems and their impacts on food security and sustainable development in Africa. Ethiopia: Economic Commission for Africa; 2004. p. 1-132.

19. Bruce JW, Migot-Adholia S. Searching for land tenure security in Africa. USA: Kendall/Hunt Publishing Company; 2016. p. 1-296.

20. Mdemu MV, Mziray N, Bjornlund H, et al. Barriers to and opportunities for improving productivity and profitability of the Kiwere and Magozi irrigation schemes in Tanzania. International Journal of Water Resources Development. 2017;33(5):725-739.

21. Moyo M, van Rooyen A, Moyo M, et al. Irrigation development in Zimbabwe: Understanding productivity barriers and opportunities at Mkoba and Silalatshani irrigation schemes. International Journal of Water Resources Development. 2017;33(5):740-754.

22. Uphoff N. Improving international irrigation management with farmer participation: Getting the process right. USA: Westview Press; 1986.

23. Stirzaker R, Mbakwe I, Mziray N. A soil water and solute learning system for small-scale Irrigators in Africa. International Journal of Water Resources Development. 2017;33(5):788-803.

24. Mziray N, Mdemu MV. Baseline data survey report: Kiwere and Magozi irrigation schemes in Tanzania. Increasing irrigation water productivity in Mozambique, Tanzania and Zimbabwe through on-farm monitoring, adaptive management and agricultural innovation platforms. Tanzania: Ardhi University; 2015.

25. Manero A. Income inequality within smallholder irrigation schemes in Sub-Saharan Africa. International Journal of Water Resources Development. 2017;33(5):770-787.

26. De Sousa W, Ducrot R, Munguambe P, et al. Irrigation and crop diversification at 25 de Setembro irrigation scheme in Boane district. International Journal of Water Resources Development. 2017;33(5):705-724.

27. Tripp R, Rohrbach D. Policies for African seed enterprise development. Food Policy. 2001;26(2):147-161.

28. Sperling L, Mcguire S. Understanding and strengthening informal seed markets. Experimental Agriculture. 2010;46(2):119-136. 